\title{
Interactive comment on "Late Miocene to Recent High Resolution Eastern Equatorial Pacific Carbonate Records: Stratigraphy linked by dissolution and paleoproductivity" by Mitchell Lyle et al.
}

\section{Mitchell Lyle et al. \\ mlyle@coas.oregonstate.edu}

Received and published: 8 March 2019

The comment was uploaded in the form of a supplement:

https://www.clim-past-discuss.net/cp-2018-157/cp-2018-157-AC1-supplement.pdf

Interactive comment on Clim. Past Discuss., https://doi.org/10.5194/cp-2018-157, 2018. 